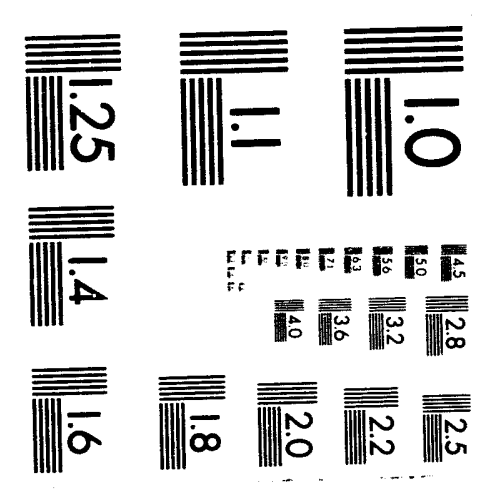



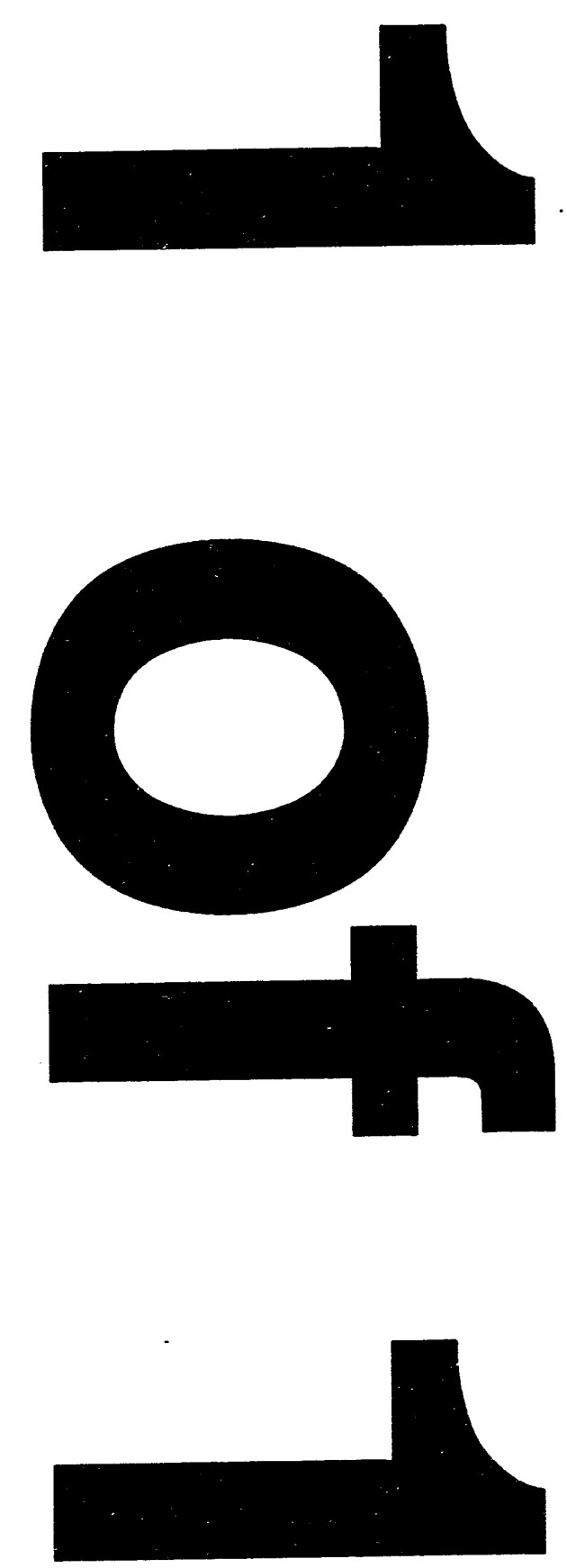


\section{GENERAL MLCTRIC}

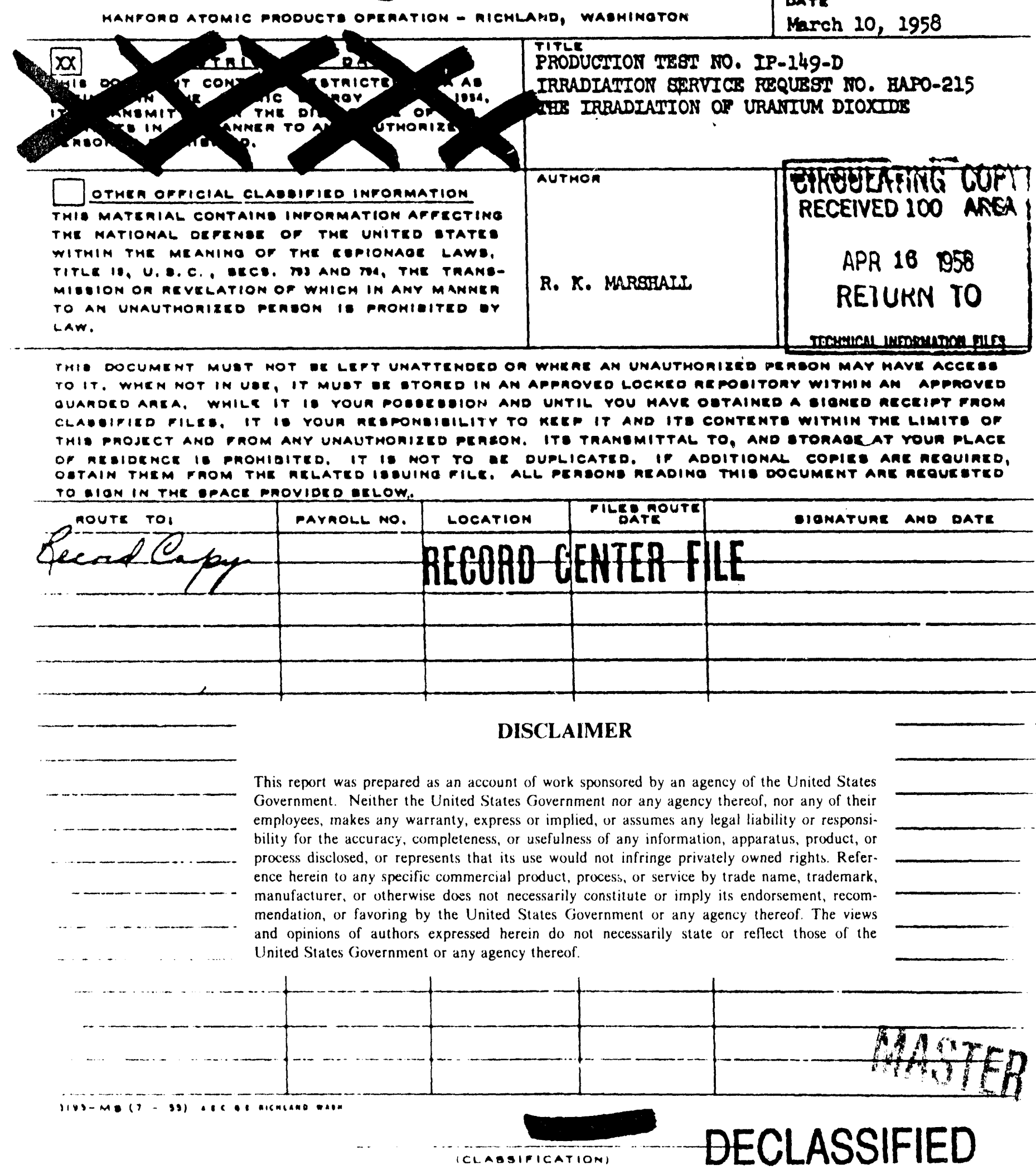

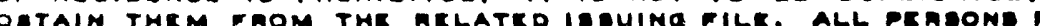
TO WION IN THE EPACE PROVIDED ERLOW.

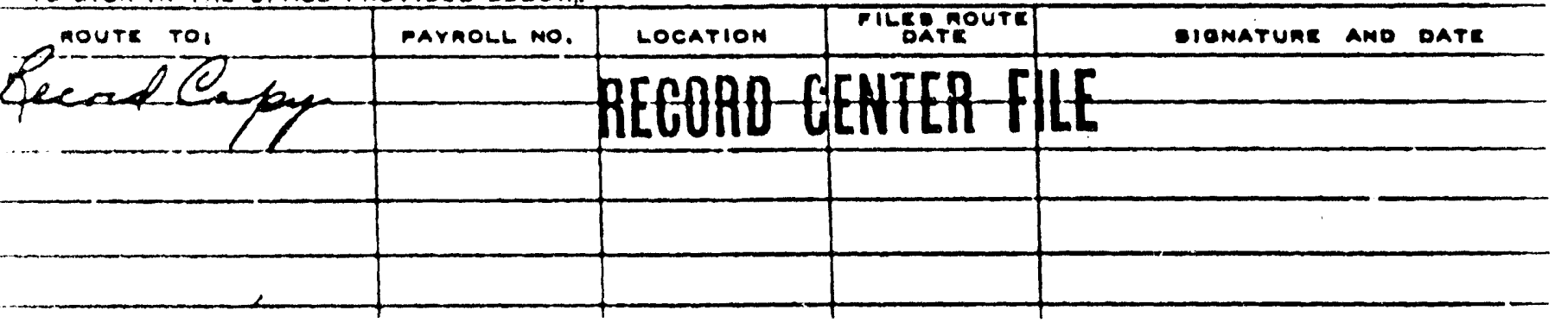

\section{DISCLAIMER}

This report was prepared as an account of work sponsored by an agency of the United States Government. Neither the United States Government nor any agency thereof, nor any of their brity for the accuracy, completeness, or usefulness of any information, apparatus, product, or and opinions of authors expressed herein do not necessarily state or reflect those of the United States Government or any agency thereof. 


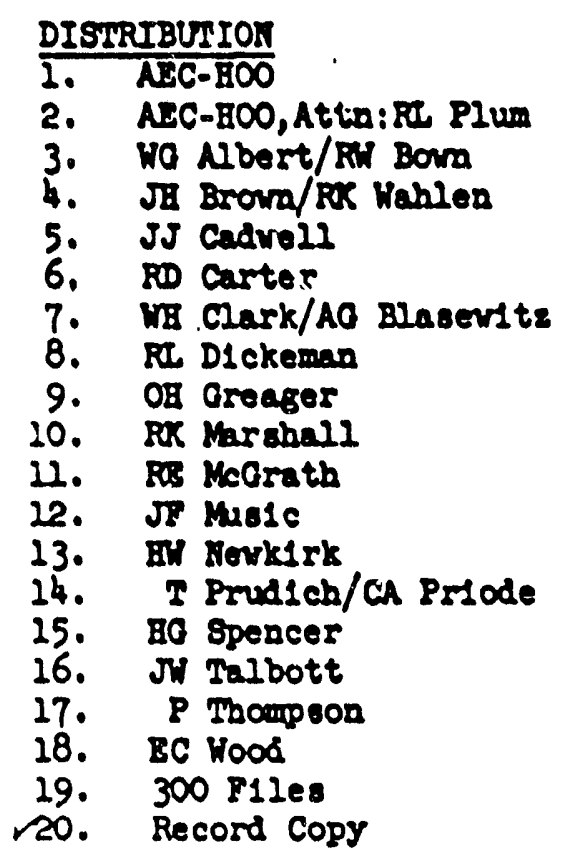

Th1s document claselfled by

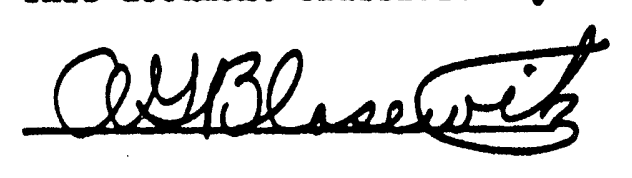

Th1s document consists of

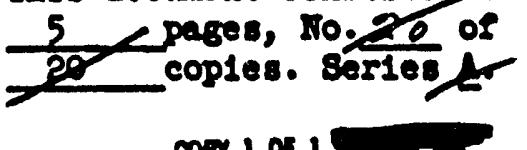

cort 1 of 4 thing ins

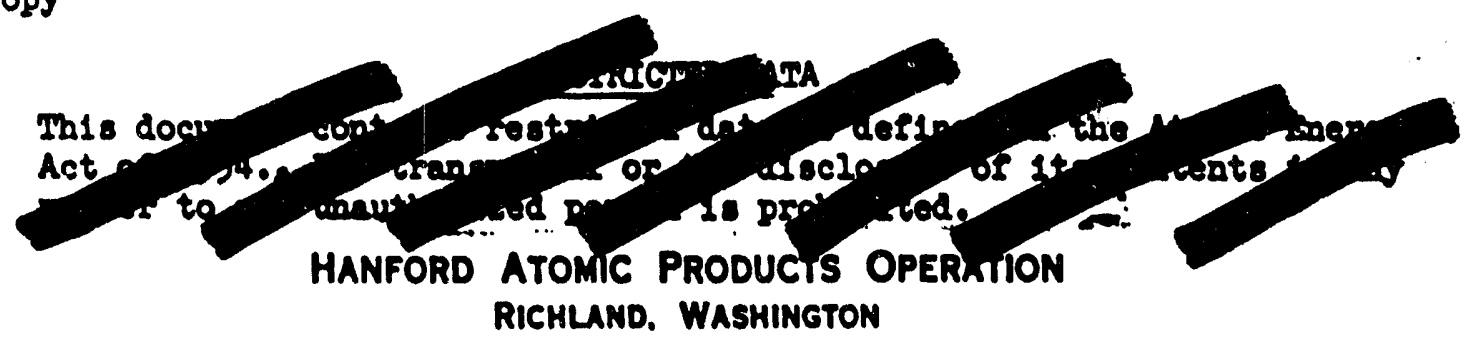

\section{PRELIMINARY REPORT}

This report wos propored only for une within Conoral Eloctik Compony in the cours of work under Atomic Enorey Commlaston Contract W-31.109-Eng-52. Any vious or opintons expresend in the repent are those of the euthors enly."

\section{LEGAL NOTICE}

Thls repont was propored as an account of Covernment sponsored works. Nelther the Unlted States nor the Commlialon, nor ony person octing on bohalf of the Commlsalons

A. Makes ony warronty or representation, express or Impllod, with respect to the eccuracy, com. pleteness, or veofulness of the information contoined in this roport, of that the use of any information,

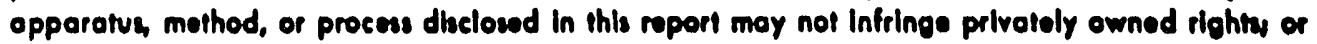

B. Asumes any llabililles wilh respect to the use of, or for domages rosulting from the use of ony Informatlon, apparofvi, method, or process dlsclosed in this roport.

As used in the above. "ponon acting on behalf of the Commlsalon" Includes any employes of controctor of the Commlacion to the extent thet eweh employee en centractor propares, handles of diatritb. user of providos occess to, any information pursuant to his employment of contract with the Commisalon. 


\section{DECLASSIFIED}

$$
-2-\quad \text { HW- } 55261
$$

PRODUCTION TEST NO. IP-249-D

IRRADIATION SERVICE REQUEST NO. HAPO-215

THE IRRADIATION OF URANIUM DIOXCDE

BASIS AND JUSTIFICATION

Fuel elements of uranlum dioxide ( $\left.\mathrm{VO}_{2}\right)$ are beling lnvestlgated for use in high teuperature vater cooled reactors. The principal advantages of uranlum dioxido are 1ts high melting polat $(2750 \mathrm{C})$ and 1ts chemlcal Inertaess to high temperature vater. To date, no determinations of the thermal conductivlty of 1 rradlated $\mathrm{VO}_{2}$ have been reported. Knowledge of this physical property of VO 18 required in order to intelligently evaluate this material as a ruel element for hlgh temperature operation.

\section{OBJECIIVE}

The objective of this test is to authorize the 1rradiation of specimens of uranium dloxide upon which thermal conductivity measurements can be made.

REACIOR AND FACILITIES REQUIRED

A maximum of elght eringe process tuhe.1 in DR.

DETAIIS OF ASSEMRTIES

The specimens to be 1rradiated are cylindrlcal rods of $\mathrm{UO}_{2}$ each three inches $100 \mathrm{~B}$ by one-fourth 1nch in dismeter. The rods are fabricated by extruding, hydrostatically pressing, and sintering $\mathrm{VO}_{2}$ porder. The density of the apecimens 18 approximately $10 \mathrm{gm} / \mathrm{cm}^{3}$. E1 ght spscimens are canned in an elght Inch Banford fuel element can as 11lustrated in P1gure 2. The rold opaces in the can are $1121 \mathrm{ed}$ ith hellum after ih1ch the can 18 sealed by relding. All relds are $x$-rayed and the cans are bellum leak tested and autoclaved. The UO, rods are brittle and thus subject to breakage so springs are located at each end of each specimen rod to absorb same of the shock which resulte from normal handling.

\section{DETAILS OF IRRADIATION}

React1v1ty Los8: None

Procedure: Elght cans each contalalng elght specimens are to be Irradiated in a region of low neutron flux ( 1 or $2 \times 10^{13} \mathrm{n} / \mathrm{cm}^{2}-\mathrm{sec}$ ) according to the following schedule:

Length of Irradiations (Months) $1 \quad 3 \quad 6 \quad 9 \quad 12$

No. of Cans Discharged 112422

The cans aro to be charged Into any of the central tweaty tubes in Row 46. For the one month 1rradiation, one can 18 to be charged 1nto one of the presently loaded central tubes in the top row and sontod agalnat the existing mint column.
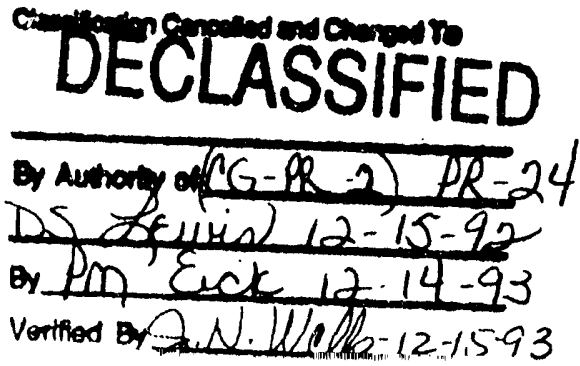


\section{DECLASSIFIED}

$$
\text { -3- } \quad \text { BN-55261 }
$$

Th1s colum 18 to be discharged after the can has been exposed for approximately one month. The same procedure is to be folloved for the three months'1madiation. For the temalning 1rradiations of two cans each for 6,9 , and 12 months, the same prosedure or an alternate one may be followed. The alternate procedure requires discharging existing mint colums. The new colums are made up as follows:

1. A standard downstream dum pattern 18 charged except the farthest up- . -tream plece 1s replaced with one sample can.

2. A standard mint colum 1s charggd.

3. One rample can 18 charged upstream of and seated agalnst the mint colum.

The ent1ry colum 18 discharged after the desired exposure. Because of the brittle nature of ive specimens, the charging and discharging of the mint metal and the sample cans must be done by hand. The chargling machine cannot be used. A special plckup of the sample cans 18 requested lmediately after each colum 18 discharged.

\section{Reactor Dorn T1me Regulred}

The t1me whlch would be required to charge and discisarge by hand the number of process tubes required to complete the 1rradiat1ons.

\section{EEAT GETERATION}

The heat generation of von havlag a density of $10 \mathrm{gm} / \mathrm{cm}^{3}$ and exposed to a slux of $3 \times 1013 \mathrm{n} / \mathrm{cm}^{2}-\mathrm{sec} 1 \mathrm{~s}$ approximately 7 vatts per gram. Calculations predict that the surface temperature of the 002 samples w1ll be less than $150 \mathrm{C}$.

\section{RAZARDS}

No hazards other than those normally asisoclated with the charge and discharge of $n$ mint colum by hand.

\section{RESPONSIBILITY}

DR Processing Operation w1ll be responsible for scheduling the tests and for the operational oafety and production continulty of the reactor. R. $X$. Marshall and A. G. Blasew1tz, Irradiat1on Testing Operat10n, hare responsib1lity for the laterests of the Research and Englneerlas Operation.

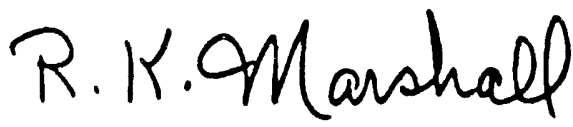

R. K. Marshall

Irradiation Test1ng Operation IRRADIATION PROCESSINO DEPARIMENT 


\section{DECLASSIFIED}

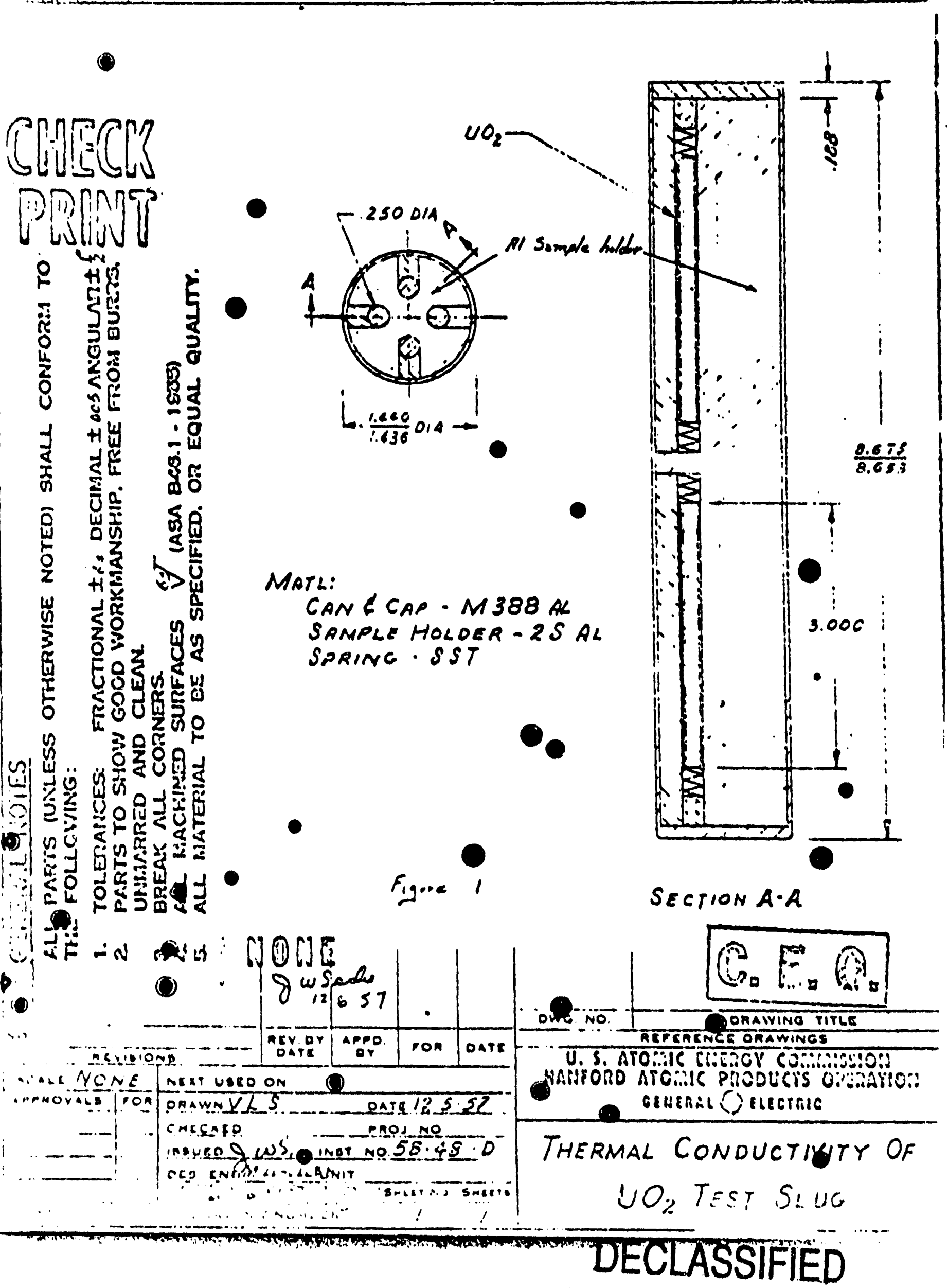


- DECLASSIFIED

$-5-$

$H N-55261$

0

0

APPROVAL

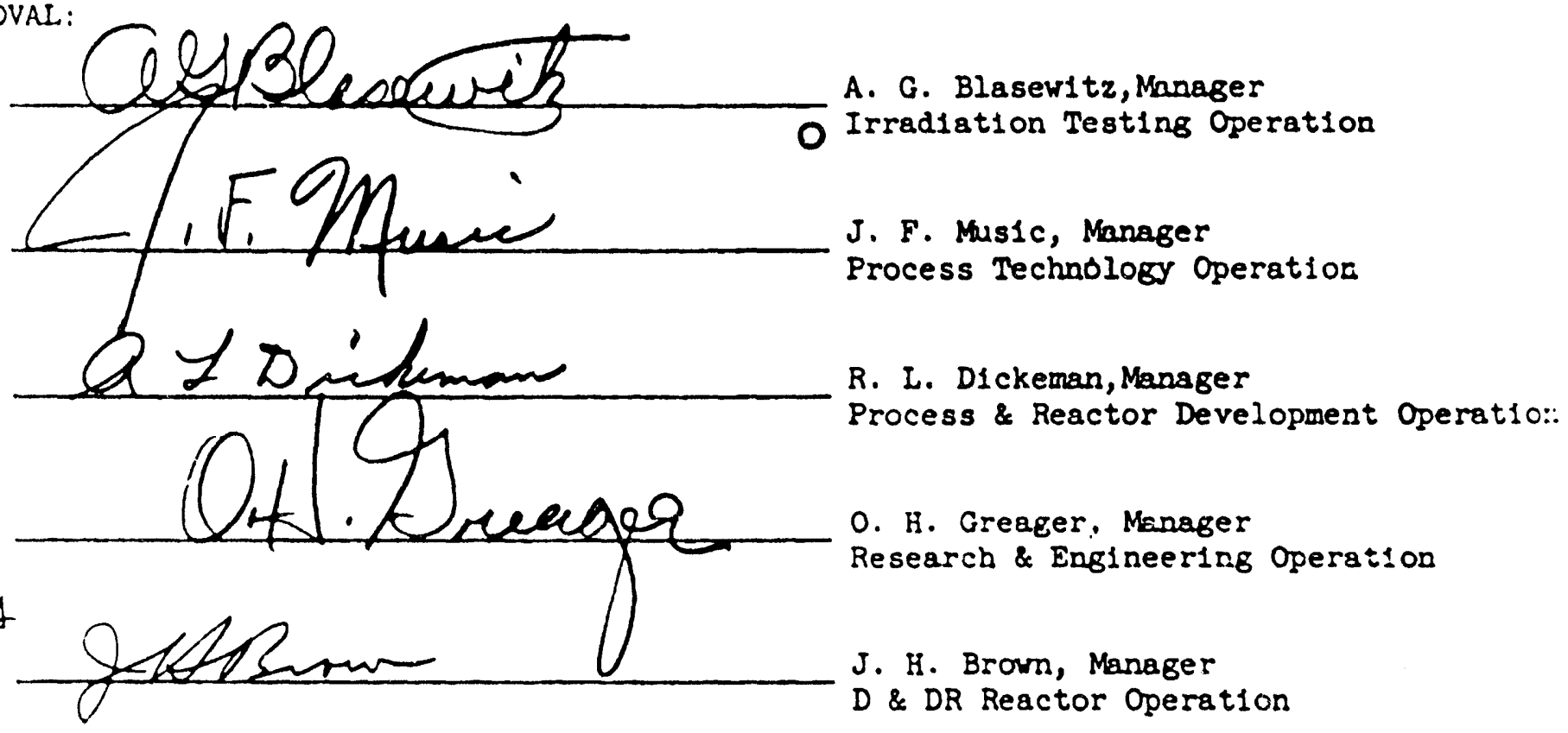

0

0

o

Date of Issue Apr 1] 8,1258

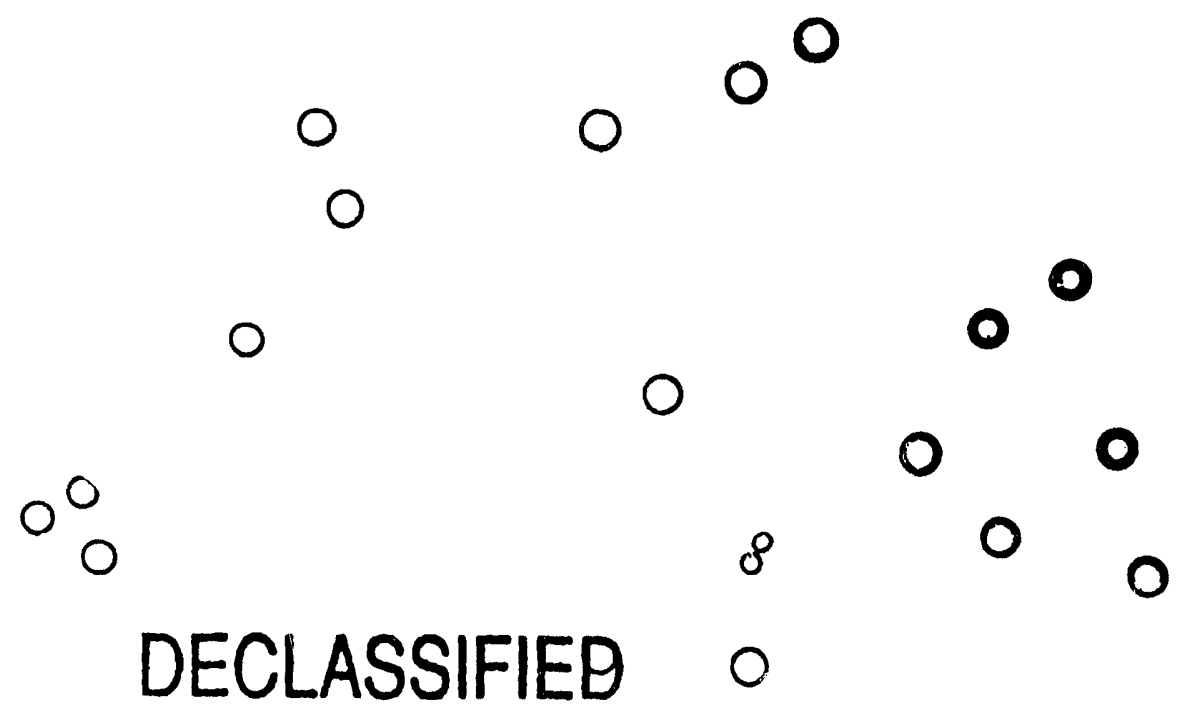

- 

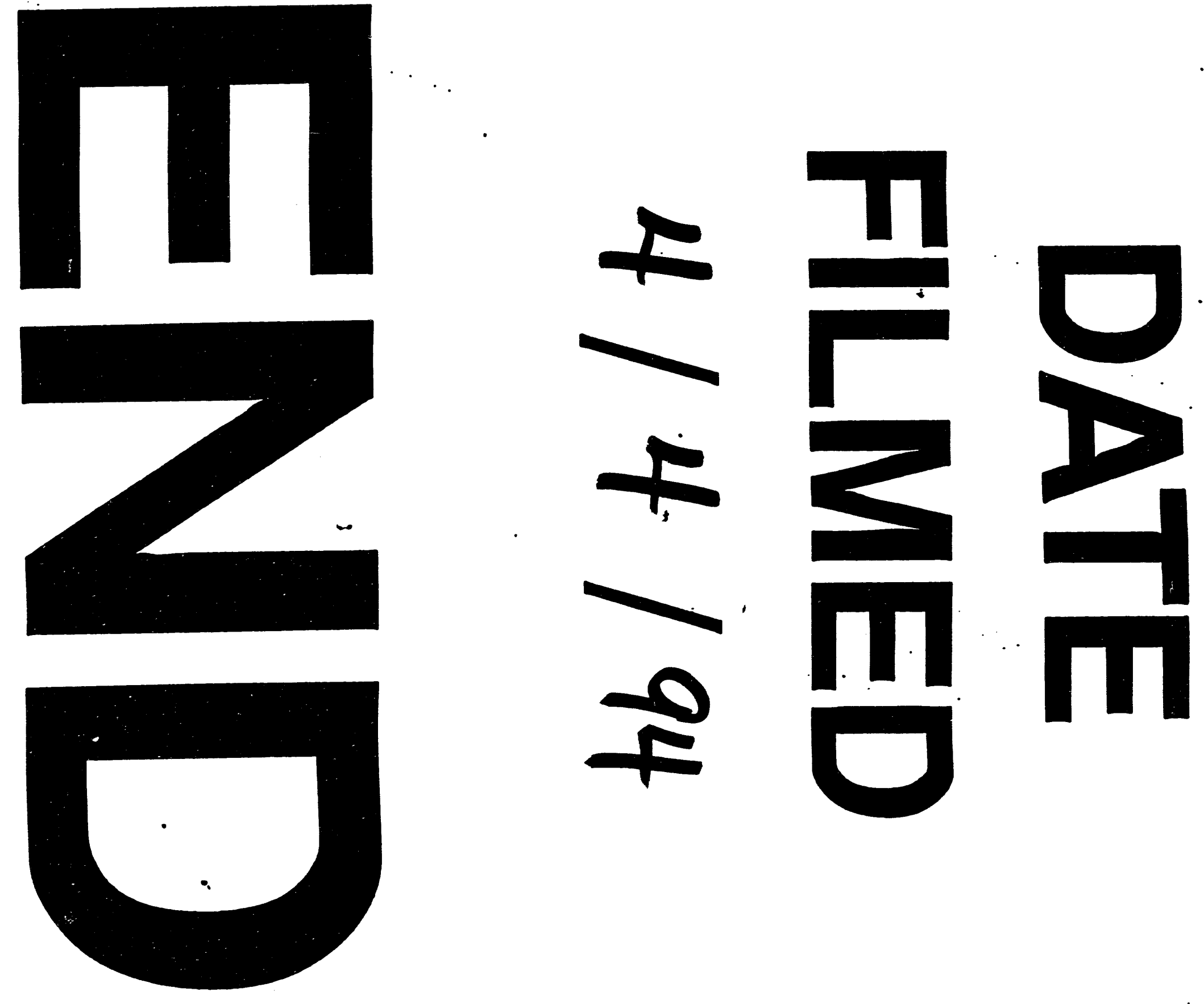
